\title{
Lars Nyre: Sound media. From live journalism to music recording. London: Routledge. 2008
}

\section{Ansa Lønstrup}

MedieKultur 2010, 48, 139-140

Published by SMID | Society of Media researchers In Denmark | www.smid.dk The online version of this text can be found open access at www.mediekultur.dk

The first text line on the back cover of the book says: "Everyday life is full of soundscapes created by professionals". So, Sound Media examines "how music recording, radio broadcasting and muzak influence people's daily lives" (ibid.), by presenting the creative techniques developed in music and journalism throughout the twentieth century.

The first half of the book introduces current techniques, including the digitalization of sound media. The second half establishes a "Backward History", by examining the historical accumulation of techniques and sounds in sound media: from the present back to the invention of the phonograph in 1877. All in all, the notion of backward history is the most original offering of this book. The question is, however, what is gained by this construction, i.e. what kind of knowledge does it produce and for whom might it be of interest?

Throughout the book, the author presents and uses historical sound examples or "case studies" from the time period in question, and they are all analysed according to the same four characteristics (parameters): 1) time (duration, chronology, causes and effects); 2) space (directions, shapes, volumes, distances); 3) personal expressiveness (emotions, moods); and 4) coded message (e.g., news and love songs) - or in short: time, space, personality and message. All the examples are included on soundtracks on a CD, which represents a fantastic source in itself.

It might be questioned, nonetheless, whether those four characteristics (parameters) used in the analyses provide any new knowledge that the reader/listener has not read or heard herself or did not know beforehand. Some of the registrations in the listening analyses 
are quite conventional stereotypes and could be criticised for their repetition of, without questioning, the relation between and representation of, for example, voice and emotion.

In the short introductory chapter on theory, the author states that he has been inspired by, among many others, Don Ihde's Listening and Voice ( $1^{\text {st }}$ edition published in $1976,2^{\text {nd }}$ edition published in 2007), which represents a very stringent phenomenological listeninganalytical methodology. Unfortunately, this approach is not characteristic for the analyses in the current book. Most of them are hardly analyses, but rather common sense and mechanical descriptions, lacking any focussed or analytical discursive openings to the "acoustemologies" of the sound examples as soundscapes.

One might doubt whether the book delivers explanations on "how music recording, radio broadcasting and muzak influence people's daily lives" (back cover text) - and whether it is possible or fruitful to historicize such different kinds of sound media phenomena in one book and one history text - without it suffering from a too generalized and "teleological" way of writing sound media history. This problem is not solved by writing the history backwards, nor by a low or too general level of methodological reflection.

However, the author succeeds in creating a thorough and very well-informed historical and technical reading - backwards - of the sound media "accumulation" that is taken for granted today, especially by younger generations. Perhaps this book is the first to do so, though it draws on an increasing amount of literature on sound, soundscapes and media. Furthermore, the very pedagogical arrangement, with several models, drawings, timeline figures and of course the CD, makes the book an obvious choice for use in the ongoing development of sound media as a subject taught in, for example, high schools.

Nevertheless, the book suffers from its lack of a focussed hypothesis, which could have secured a more problem-oriented way of presenting the history, as well as it might have strengthened the analyses of the (listening) examples. The book also thoroughly describes the quite technical facts about the sound media as technologies. This again points in the direction of a pedagogical textbook, best suited for pupils/students at a middle level and not - as the book also claims on the back cover - for scholars.

Ansa Lønstrup

Associate Professor, Ph.D. Department of Aesthetic Studies University of Aarhus, Denmark aekal@hum.au.dk 